\title{
Two new Holocene vegetation records from the margins of the Canterbury Plains, South Island, New Zealand
}

\author{
Jamie R. Wood $^{1 *}$, Janet M. Wilmshurst ${ }^{1,2}$ and Matthew S. McGlone ${ }^{1}$ \\ ${ }^{1}$ Long-term Ecology Lab, Landcare Research, PO Box 69040, Lincoln 7640, New Zealand \\ ${ }^{2}$ School of Environment, University of Auckland, Private Bag 92019, Auckland 1142, New Zealand \\ *Author for correspondence (Email: woodj@landcareresearch.co.nz)
}

Published online: 23 May 2018

\begin{abstract}
Canterbury's gravelly outwash plains offer few of the natural deposits in which floral remains are typically preserved and hence represent a significant geographical gap in our knowledge about New Zealand's pre-settlement terrestrial ecosystems and their response to anthropogenic activities. We contribute new insights into the poorly known Holocene vegetation history of this region by reporting two new mid-late Holocene pollen records from the western (Hallsbush) and eastern (Travis Swamp) margins of the Canterbury Plains. Both records show local forest dominance prior to Polynesian settlement. Forest was cleared rapidly after human settlement at the eastern site, but despite local fires that burnt the wetland the forest was retained at the western site until after European settlement. Together with the few pollen records previously published from the margins of the Canterbury Plains, a clear pattern of beech forest dominance in the west and podocarp/hardwood forest dominance on the plains to the east at the time of human settlement emerges. However, additional sites on the Canterbury Plains are essential for a better understanding of the pre-settlement composition and heterogeneity of vegetation communities within this region.
\end{abstract}

Keywords: beech; deforestation; fire; forest composition; palaeoecology; palynology; podocarp

\section{Introduction}

The Canterbury Plains, which extend from the flood plain of the Rangitata River in the south to that of the Waimakariri River in the north (Fig. 1), represent a significant geographical gap in our knowledge about New Zealand's pre-settlement terrestrial ecosystems and their response to the onset of anthropogenic actitives. These gravelly outwash plains offer little in the way of lake or wetland deposits where floral remains are typically preserved. The limited deposits that do exist therefore provide an important window into the past ecology of the Canterbury Plains, improving our understanding of the natural ecosystems of the region and of the impact of past human activities on the vegetation. Analyses of such deposits can also provide important baseline data for guiding ecological restoration projects on the Canterbury Plains.

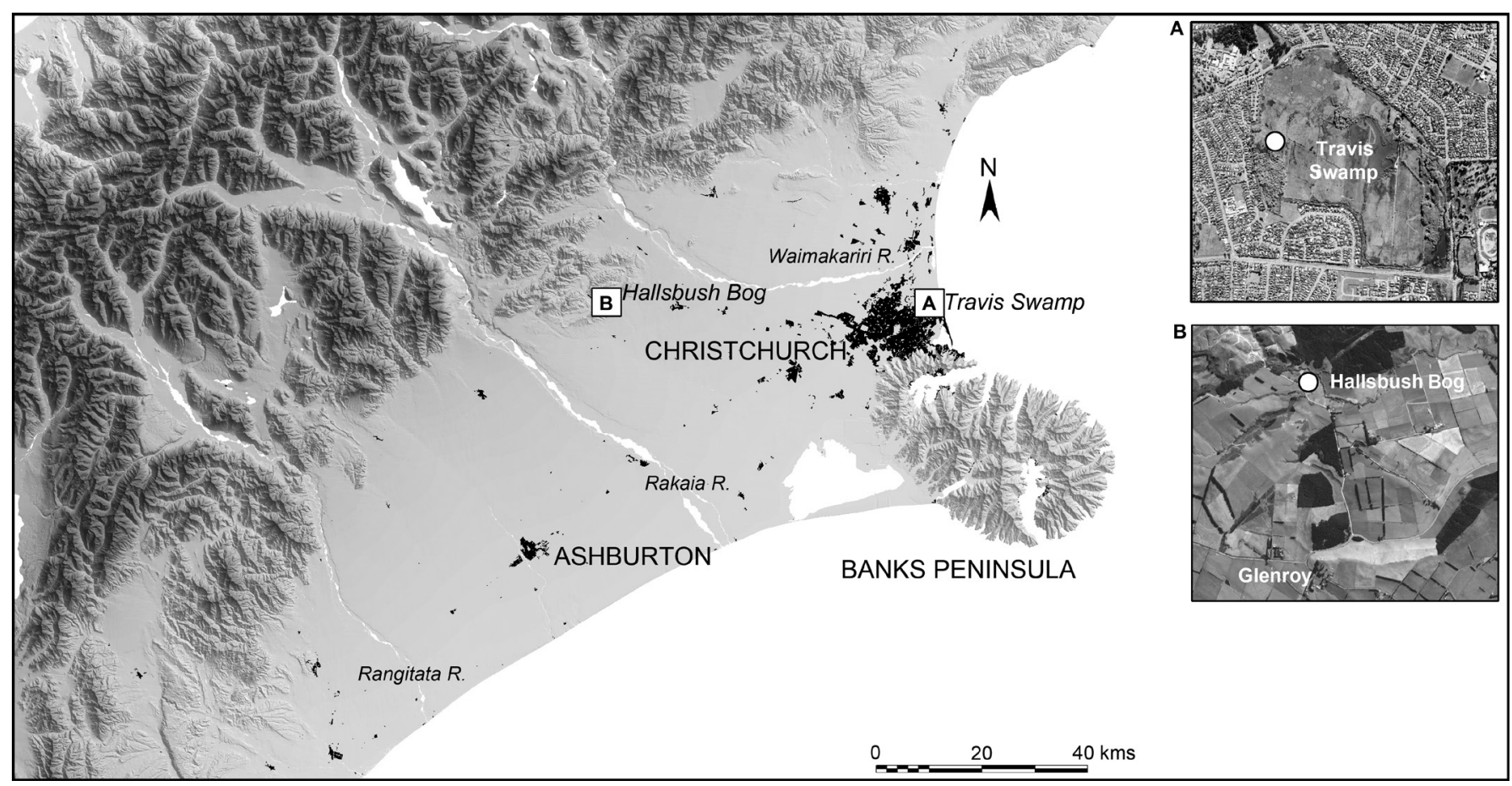

Figure 1. Canterbury plains, showing location of new pollen records presented in this paper. New Zealand Journal of Ecology (2018) 42(2): 240-247 (C) New Zealand Ecological Society. 
Early investigations of the past vegetation on the Canterbury plains and adjacent uplands relied on charcoal and wood preserved in gravel and silt deposits (Speight 1911; Raeside 1948; Cox \& Mead 1963; Molloy et al. 1963; Molloy \& Cox 1972; Molloy \& Ives 1972). The Holocene vegetation of the plains was summarised on the basis of soil, charcoal and wood evidence by Molloy (1968), who postulated that podocarp forest, including mataī (Prumnopitys taxifolia), miro (P. ferrruginea), tōtara (Podocarpus totara) and thin-barked tōtara (P. laetus; after Molloy 2015), formerly grew on the silt-dominant soils within the flood plains of the major rivers. On the stonier, older and more drought-prone interfluves, he suggested that stunted $P$. laetus coexisted with low kānuka (Kunzea) forest. Rare remnants of the latter vegetation type still exist on the Canterbury plains, such as at Eyrewell Scientific Reserve north of the Waimakariri River(Molloy and Ives 1972).

Palynological records provide a broader and more representative range of information about past vegetation communities than do charcoal and macrofossils. Although late Quaternary palynological records exist for the wider mid-Canterbury region, they tend to be concentrated either at high-altitude sites or inland montane basins (e.g. Moar 1971; 1973; Lintott and Burrows 1973; Burrows \& Russel 1990; Burrows et al. 1993; Burrows 1995; Burrows \& Moar 1996; McGlone et al. 2004) and/or be early-Holocene or older in age (e.g. Moar \& Gage 1973; Burrows \& Moar 1996; Shulmeister et al. 1999). Just eight late Holocene pollen records exist from low altitude sites on, or adjacent to, the Canterbury Plains. These are concentrated along the south-west margin of Banks Peninsula (Moar \& Mildenhall 1988; Woodward \& Shulmeister 2005; van Dijk 2011) and along the east Coast from Christchurch to Mt Cass (Moar 1971; 2008) (Fig. 1). All of these records demonstrate significant loss of woody vegetation communities associated with human arrival, from initial Polynesian settlement $\left(13^{\text {th }}\right.$ Century AD) through to the time of European landscape modification (mid-19 ${ }^{\text {th }}$ Century to present).

Here, we summarise existing pollen records from the Canterbuy Plains and contribute new insights into the Holocene vegetation history of this region by reporting two new mid-late Holocene pollen records from the western and eastern margins of the Canterbury Plains.

\section{Methods}

\section{Study sites}

\section{Hallsbush Bog}

A $150 \mathrm{~cm}$ long core was collected using a D-section corer from a small spring-fed bog adjacent to the QEII covenanted forest remnant at Hallsbush in the Wairiri Valley (Landcare Research site code X01/12; approximately 43 $30^{\prime} 07.5^{\prime \prime} \mathrm{S}$, $171^{\circ} 50^{\prime} \mathrm{E}$ ). The bog is situated at $300 \mathrm{~m}$ above sea level on the margin of the Canterbury foothills and the western edge of the Canterbury Plains (Fig. 1) and contained homogenous wellhumified reddish-brown sedge peats to at least $200 \mathrm{~cm}$ depth.

\section{Travis Swamp}

A $200 \mathrm{~cm}$ long core was taken in the western sector of Travis Swamp, approximately $250 \mathrm{~m}$ from the terrace that marks the edge of the swamp and $80 \mathrm{~m}$ north of the area of extensive grey willow (Salix cinerea) (Landcare Research site code X95/7; approximately $43^{\circ} 29^{\prime} 08.9^{\prime \prime} \mathrm{S}, 172^{\circ} 41^{\prime} 13.6^{\prime \prime}$ E) (Fig. 1).
The swamp is $<20 \mathrm{~m}$ above sea level. The ground surface was dry at the time of sampling and the vegetation at the core site was almost entirely glaucous sedge (Carex flacca). The stratigraphy of the core was as follows: $0-12 \mathrm{~cm}$, dark-brown peat with numerous live sedge roots; $12-35 \mathrm{~cm}$, dark-brown humified sedge peat; $35-45 \mathrm{~cm}$, grading into the unit below; 45-80 cm, red-brown sedge peat; $80-109 \mathrm{~cm}$, fine structured dark-brown peat (wood fragment noted at $93 \mathrm{~cm}$ ); 109-112 $\mathrm{cm}$, peat with sedge bases; 112-144 cm, light-grey, banded organic-rich clay with occasional silt and sand; 144-175 $\mathrm{cm}$, blue-grey silty sand with flecks of dark-brown organics; 175-200 cm, grades down to coarse sand.

\section{Palynology}

Both cores were sub-sampled along their length for pollen analysis. The outer contaminated surfaces of the cores were removed by scraping horizontally and $0.6 \mathrm{~cm}^{3}$ subsamples were taken at regular intervals from the cleaned faces. These were processed for pollen analysis using the standard protocol: disaggregation of the sample and boiling in $10 \% \mathrm{KOH}$; sieving with a $100 \mu \mathrm{m}$ mesh; digesting in $40 \% \mathrm{HF}$ acid; acetolysis; staining and mounting on a microscope slide in glycerine jelly (Moore et al. 1991). A total of 250 pollen grains were counted from each sample to calculate pollen percentages (sum excludes pollen from wetland taxa and fern spores other than Pteridium, as their typically high abundances tend to dominate and obscure the sum). Microscopic charcoal abundance was determined through point counting (using an 11 point grid per field of view) and the result expressed as a percentage of the terrestrial pollen sum (Clark 1982). Boundaries between different pollen zones were determined based on marked changes in the dominant pollen types and charcoal abundance. For the Travis Swamp core, detailed quantification of pollen and charcoal was performed in the upper $50 \mathrm{~cm}$. Microscope slides were made from the lower part of this core, but only scanned for the dominant pollen types. Therefore, only the pollen data from the upper $50 \mathrm{~cm}$ is presented in the pollen diagram (Fig. 3).

\section{Radiocarbon dating}

Bulk peat samples were taken from the Hallsbush core at depths of $52 \mathrm{~cm}$ and $150 \mathrm{~cm}$ and were submitted to the Waikato Radiocarbon Dating laboratory, Waikato University, for Accelerator Mass Spectrometry (AMS) radiocarbon dating. Peat samples from the Travis Swamp core were taken at 138, 113 and $37 \mathrm{~cm}$ depths and were submitted to the New Zealand Radiocarbon Dating Laboratory (Lower Hutt) for AMS radiocarbon dating. Radiocarbon dates were calibrated using the ShCal13 calibration (Hogg et al. 2013) in OxCal v.4.2 (Bronk Ramsey 1995).

\section{Results}

\section{Hallsbush Bog}

The pollen record from Hallsbush Bog (Fig. 2) comprises five distinct zones, reflecting differences in the dominant pollen types deposited at the site through time. These zones are described below in chronological order.

Zone $5(150-70 \mathrm{~cm})$. The pollen assemblage of zone 5 is dominated by mataī (Prumnopitys taxifolia), with lesser amounts of miro (Prumnopitys ferruginea), rimu (Dacrydium 

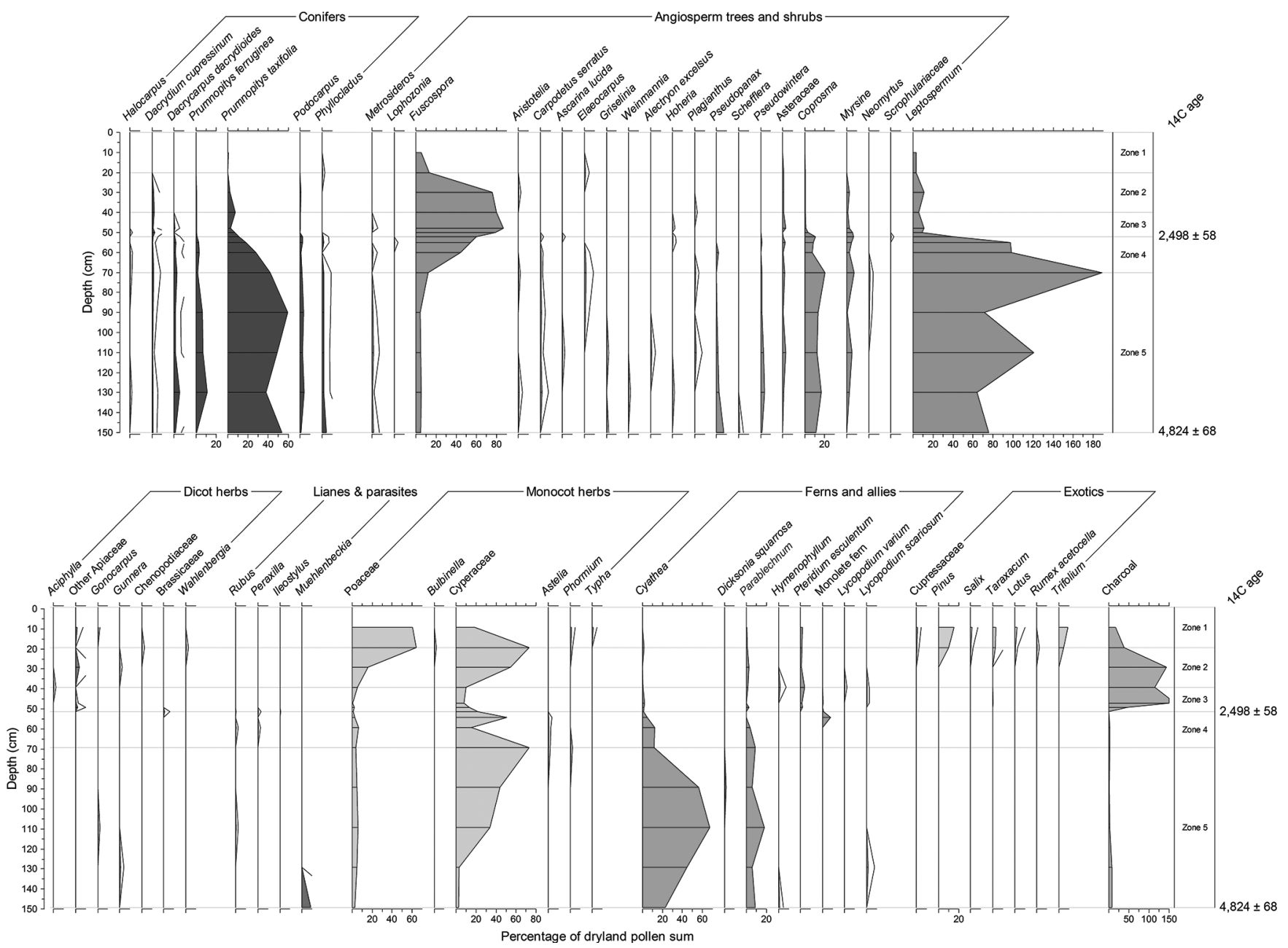

Figure 2. Pollen diagram from Hallsbush Bog, Wairiri Valley, South Island, New Zealand.

cupressinum), tōtara (Podocaprus totara), tree ferns (Cyathea smithii and Dicksonia squarrosa) and many hardwood tree taxa. Pollen from plants likely to have been growing directly on the bog is dominated by mānuka (Leptospermum-type) and sedges (Cyperaceae).

Zone $4(70-52 \mathrm{~cm})$. Zone 4 is a transitional zone, where mataī, ground ferns (Blechnum spp.) and tree ferns (notably Cyathea spp.) gradually decline and Fuscopora beeches increased.

Zone $3(52-40 \mathrm{~cm})$. Zone 3 reflects a period of relative stability in the local vegetation community. At this time Fuscospora beeches dominated the pollen assemblage.

Zone $2(40-20 \mathrm{~cm})$. In zone 2 charcoal increased sharply and bracken (Pteridium esculentum) was recorded consistently for the first time. Grasses became increasingly abundant towards the surface, whereas mānuka (Leptospermum-type) and Coprosma pollen declined sharply.

Zone $1(0-20 \mathrm{~cm})$. The uppermost zone of the core is marked by the sudden appearance of pollen from exotic species, in particular pine (Pinus), macrocarpa (Cupressaceae), willow (Salix), clover (Trifolium), sorrel (Rumex) and dandelion (Taraxacum), which collectively indicate European farming activities in the area. Charcoal and beech pollen declined and podocarp pollen was completely absent. Grass and sedge pollen became dominant. Beech was the only tall forest tree represented in the pollen spectra of this zone and was present in only minor amounts (c. $<10 \%)$.

Radiocarbon dating shows that the core extends back to the mid-Holocene, with the base $(150 \mathrm{~cm})$ having a calibrated age of 5644-5322 cal BP (95.4\% confidence) (Table 1$)$. The boundary of zones 3 and $4(52 \mathrm{~cm})$, by which point beeches had replaced podocarps as the dominant pollen type, had an age of 2715-2359 cal BP (95.4\% confidence) (Table 1).

\section{Travis Swamp}

Four distinct zones, characterised by different vegetation communities, were identified in the pollen analysis of the Travis Swamp core (Fig. 3). These zones are described below in chronological order.

Zone $4(200-38 \mathrm{~cm})$. The coarse sand at the base of the core $(175-200 \mathrm{~cm})$ did not contain preserved pollen. The organicrich clay lying above the sand had high levels of Apodasmia pollen and abundant pollen of mataī, miro, rimu and beeches. From $140 \mathrm{~cm}$ upwards there was an increase in represenation of tōtara, Coprosma, Myrsine, ribbonwood (Plagianthus regius), lacebark (Hoheria), bracken and other scrub species. From 110 cm upwards there was an increase in sedge and mānuka pollen, as well as freshwater aquatic elements such as Pediastrum 

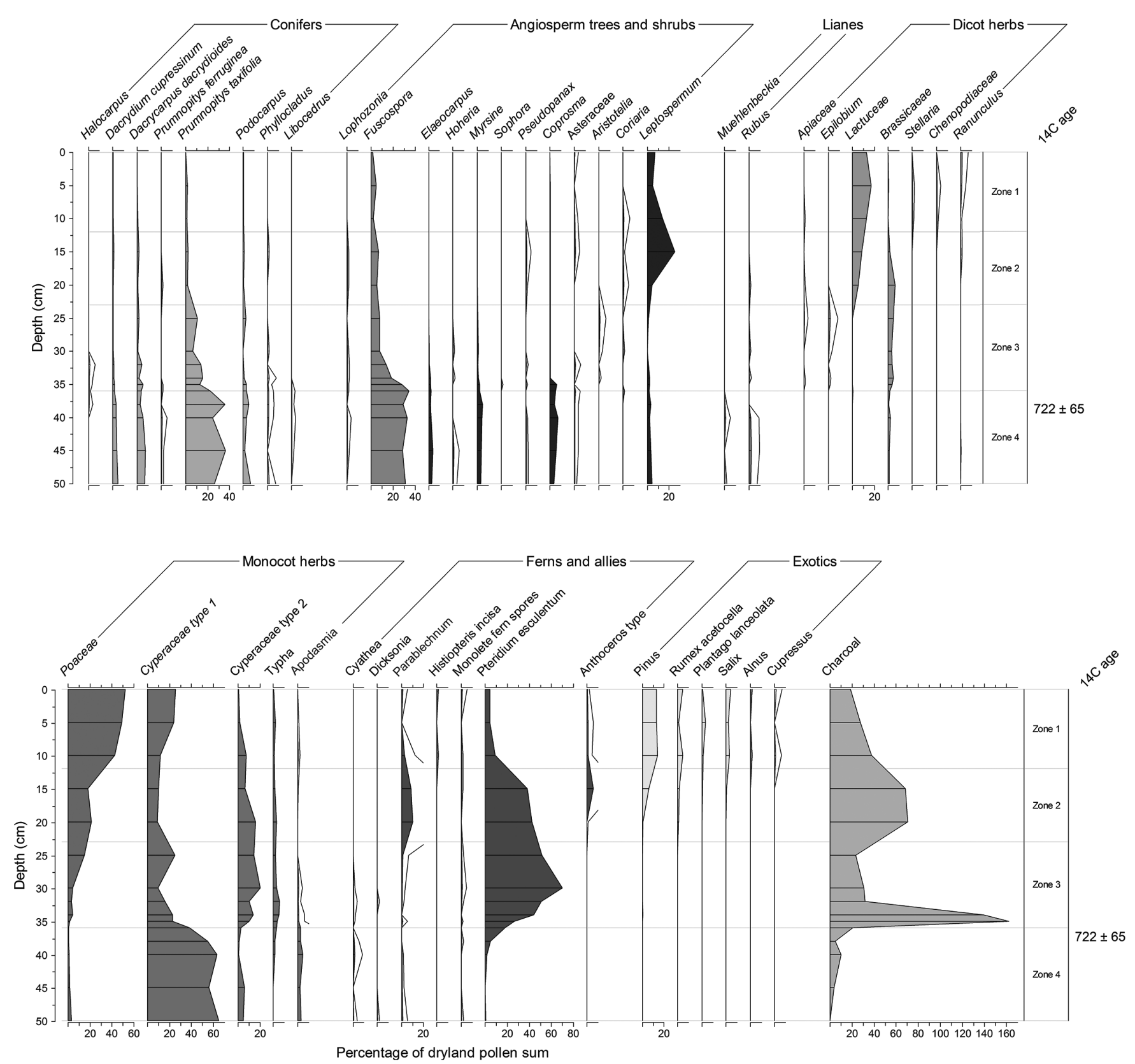

Figure 3. Pollen diagram from Travis Swamp, Christchurch, South Island, New Zealand.

Table 1. AMS radiocarbon dates from the Hallsbush Bog and Travis Swamp peat cores.

\begin{tabular}{|c|c|c|c|c|}
\hline Site & Lab code & Depth $(\mathrm{cm})$ & $\begin{array}{l}{ }^{14} \mathrm{C} \text { age and error (years } \\
\text { Before Present (i.e. AD 1950) }\end{array}$ & $\begin{array}{l}\text { Calibrated age ranges and confidence } \\
\text { (calibrated years Before Present) }\end{array}$ \\
\hline \multirow[t]{3}{*}{ Hallsbush Bog } & WK-10900 & 52 & $2498 \pm 58$ & 2715-2359 cal BP (95.4\%) \\
\hline & WK-10899 & 150 & $4824 \pm 68$ & $5644-5440$ cal BP $(73.8 \%)$ \\
\hline & & & & 5419-5322 cal BP (21.6\%) \\
\hline \multirow[t]{5}{*}{ Travis Swamp } & NZA-6649 & 37 & $722 \pm 65$ & $724-550$ cal BP (95.4\%) \\
\hline & NZA-6355 & 113 & $1341 \pm 70$ & $1320-1058$ cal BP $(95.3 \%)$ \\
\hline & & & & $1342-1339$ cal BP $(0.1 \%)$ \\
\hline & NZA-6653 & 138 & $6290 \pm 120$ & $7424-6880$ cal BP (94.9\%) \\
\hline & & & & $6871-6860$ cal BP $(0.5 \%)$ \\
\hline
\end{tabular}


(a colonial freshwater alga) and Potamogeton. By $80 \mathrm{~cm}$, Apodasmia was recorded only at low levels and mānuka was abundant. The composition of the pollen assemblage did not change markedly from $80-38 \mathrm{~cm}$ (the top of zone 4).

Zone $3(38-23 \mathrm{~cm})$. There was a steep rise in the abundance of bracken spores and a concomitant steep decline in forest trees and dryland scrub pollen types at $38 \mathrm{~cm}$. The charcoal abundance index remained low for the first few $\mathrm{cm}$ of this zone, before rising steeply and including the larger size classes of charcoal only after bracken had become the dominant pollen/spore type. Apodasmia and Leptospermum declined and Baumea-type, raupō (Typha) pollen and Sphagnum spores increased. Grass pollen increased towards the top of zone 3.

Zone 2 $(23-12 \mathrm{~cm})$. In zone 2 there was a renewed upsurge in charcoal abundance and the appearance of exotic pollen types such as sorrel and docks (Rumex). There was also a marked increase in dandelion-type pollen (Asteraceae: Lactuceae) abundance and spores of the swamp kiokio fern (Parablechnum minus). At the top of this zone, mānuka and grass pollen increased and bracken spores declined.

Zone $1(12-0 \mathrm{~cm})$. In zone 1, pollen from pine, grasses, willow and pasture weeds increased and charcoal abundance decreased, with only smaller size fragments $(<10 \mu \mathrm{m})$ remaining at relatively high abundance. Baumea-type pollen (attributable to Machaerina) was eliminated and mānuka and swamp kiokio declined.

Radiocarbon dating shows that the core likely extended back to the early Holocene, with a date of $6290 \pm 120$ years $\mathrm{BP}$ at $138 \mathrm{~cm}$ depth (Table 1). The beginning of zone 3 corresponds to a radiocarbon date of $722 \pm 65$ years BP (Table $1)$, approximately the time of initial human settlement.

\section{Discussion}

\section{Hallsbush}

The spring bog at Hallsbush began forming peat deposits prior to 5500 years ago. From this time, until about 2600 years ago, the local wetland vegetation was dominated by a shrubby cover of Coprosma, mānuka and Myrsine with sedges. Matā̄, miro, rimu, tōtara and kahikatea with the occasional beech (most likely black, red and mountain beech, but not silver) and other hardwood trees dominated the surrounding drier ground. Ground ferns such as swamp kiokio and tree ferns including Cyathea smithii were abundant. The pollen record from Hallsbush captures the mid-late Holocene transition from podocarp to beech forest dominance, which has been noted in other pollen records from across the South Island (e.g. Wilmshurst et al. 2002; McGlone et al. 2004; Turney et al. 2017).

The decline in wetland shrubs and sedges and concomitant increase in bracken fern, grasses and charcoal in zone 2 reflects early Māori burning in the area. This signal of this Initial Burning Period (McWethy et al. 2010) is also present in other pollen diagrams in the area, e.g., at Porter's Pass (Moar 2008) and more widely in the South Island (McWethy et al. 2010). The long period of time that elapses between only $52 \mathrm{~cm}$ (calibrated age of 2715-2359 cal BP) and $50 \mathrm{~cm}$ (where the anthropogenic charcoal increase begins) suggests peat accumulated very slowly during a dry period and this signature is seen in several cores from the South Island (e.g., McGlone \& Wilmshurst 1999). Although it is possible that this may represent an unconformity where peat was burnt, this is unlikely. Water saturated peats will not burn, and any loss of peat during a fire would thus be confined to the temporarily dried out surface; representing perhaps no more than a few decades. Moreover, observations after fires have shown that recovery of the peat forming plant cover occurs relatively rapidly (Timmins 1992; Johnson 2001). Interestingly, the early Māori fire disturbance seems to have only affected the wetland vegetation at this site; the surrounding beech forest was not cleared until much later in the European period. This may reflect the fact that the mix of shrubs on the wetland is likely to have been more flammable than the surrounding tall wet forest (Perry et al. 2014; Battersby et al. 2017). There is an indication that grasses were beginning to increase in dominance before zone 1 (i.e. the European farming period) and this may reflect grass pollen grains blown in from post-fire episodes elsewhere on the plains.

\section{Travis Swamp}

The coarse sand at the base of the Travis Swamp core (zone 4) likely reflects a period when the local landscape was dominated by sand dunes, with little permanent plant cover, perhaps surrounding a wetland with some tidal influence. In support of this, is the abundance of Apodasmia (Apodasmia) pollen, and the fact that the the age of the base of this core corresponds to the time when present mean sea level was first attained and may have been exceeded, in the Canterbury region(Clement et al.2016). Encroachment of taller vegetation (forest and shrub cover), is represented by an increase in these pollen types and decrease in Apodasmia pollen from $140 \mathrm{~cm}$ upwards, reflecting reduced marine influence and stabilisation of the surrounding dunes. The steep rise in the abundance of bracken spores and equally steep decline in forest trees and dryland scrub pollen types, at about $38 \mathrm{~cm}$ reflects the initial period of widespread Māori forest clearance in the Christchurch area. The radiocarbon date of $722 \pm 65(724-550 \mathrm{cal} \mathrm{BP})$ at $37 \mathrm{~cm}$ (Table 1) confirms this as the Initial Burning Period. The pollen evidence suggests that there was little forest, but substantial areas of grass and bracken surrounding the core site during the late Māori period (top of zone 3). The top of the core (zones 2 and 1) corresponds to the European era, with an increase in charcoal abundance reflecting further vegetation clearance, likely to be land clearing for agriculture. The increase in agricultural land is also reflected by an increase in pollen from grasses and agricultural weeds including Rumex and Plantago (Fig. 3).

\section{Pre-settlement vegetation of the Canterbury Plains}

The palaeovegetation records from Hallsbush Bog and Travis Swamp (summarised in Fig. 4) contribute to our wider understanding of the dominant forest types that existed on the Canterbury Plains prior to human settlement. The composition of thirteen pollen assemblages from east of the Southern Alps and at the same latitude as the Canterbury Plains, immediately prior to the timing of human settlement, shows a clear pattern in the dominant canopy species (Fig. 5). Beeches dominated pollen assemblages from the western foothills, with the exception of Mt Horrible which had approximately equal amounts of beech and podocarp pollen. Pollen assemblages from the eastern margin of the plains exhibited equal or greater amounts of podocarp pollen compared with beech pollen, and tended to be more diverse, with higher proportions of other tree and shrub taxa lianes/parasites, dicot herbs and grasses 

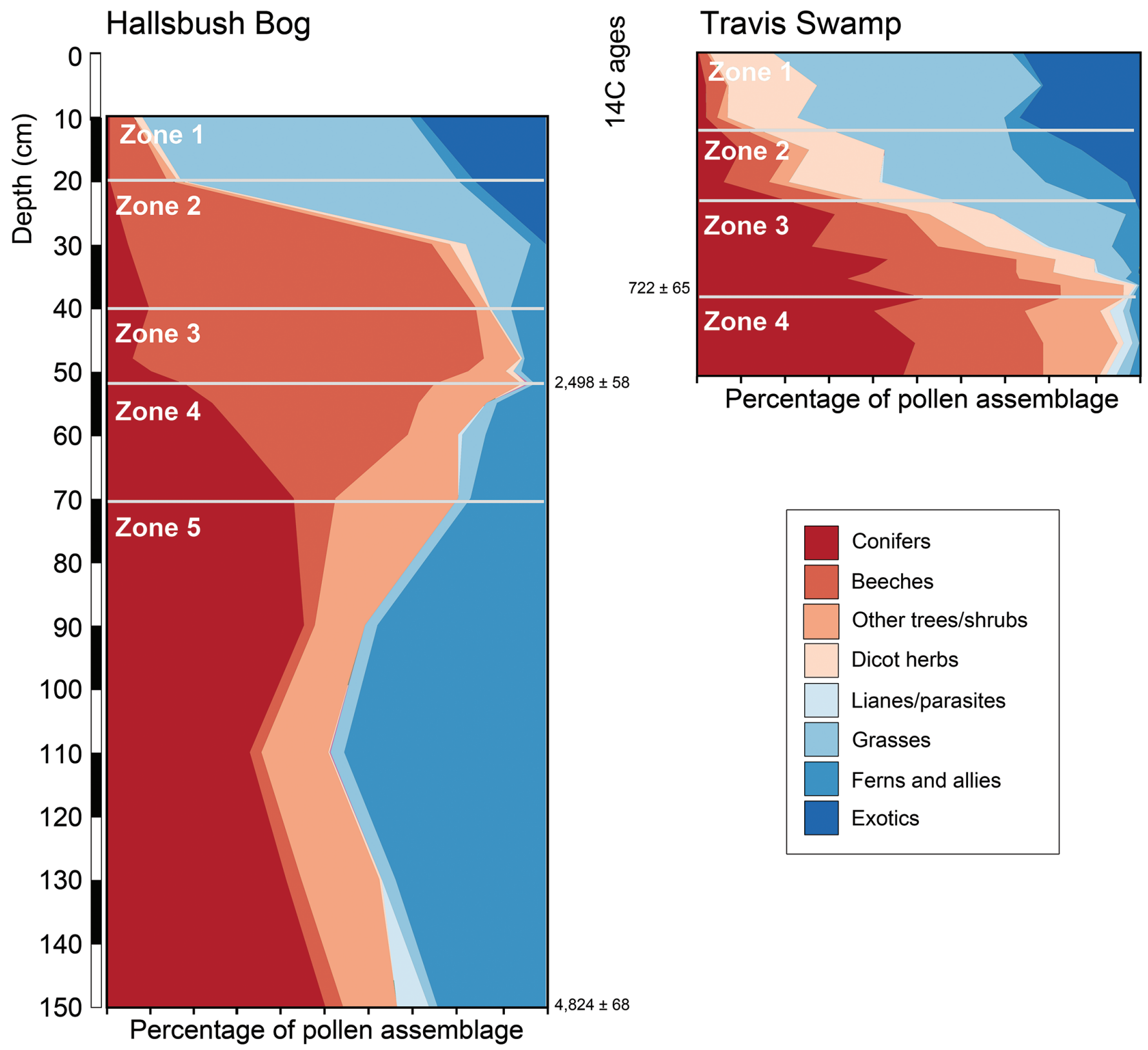

Percentage of pollen assemblage

Figure 4. Summary of key groups in the pollen records from Hallsbush Bog and Travis Swamp.

(Fig. 5). Interestingly, the frequent occurrence of kānuka in soil charcoal records (e.g., Cox \& Mead 1963; Molloy 1970; Molloy \& Ives 1972) is not mirrored by an equally frequent occurrence in the pollen records, but this is likely to be due to the fact that kānuka prefers dry sites (the pollen records are from wet sites) and its pollen does not disperse far from source. Both podocarp and beech pollen (particularly Fuscospora type) can disperse long distances (McKellar 1973; Myers 1973; Moar et al. 2011) and so the proportion of beech pollen in the eastern cores that originates from distant vs. local sources is uncertain. However, given the predominant westerly windflow across the Canterbury foothill region, the pattern observed in the pollen assemblages (Fig. 5) is consistent with beech forests having been present on the foothills along the western margins of the Canterbury plains (where beech represented $49.5-98 \%$ of pollen assemblages at the time of human settlement) (Fig. 5). Although the plains themselves were dominated by podocarp or mixed podocarp/hardwood forest types, it is likely that beeches were also locally common towards the east, perhaps in suitable micro-environments. The beech pollen in the eastern and more coastal sites is likely to be of local origin rather than wind blown from western sources of beech forest, as the wind flow becomes increasingly dominated by north easterly flows towards the coast. For example, higher proportions of beech pollen at Travis Swamp, Kaiapo Pa and Mt. Cass Road (30.9-34.1\%) compared with other eastern sites (11.4-20\%) may indicate that more beech was growing locally at these sites.

\section{Conclusions}

The pollen records from Hallsbush and Travis Swamp provide additional evidence for the pre-settlement composition of vegetation communities along the margins of the Canterbury Plains. Assessed along with other palaeovegetation records from similar locations, a consistent pattern is now emerging 


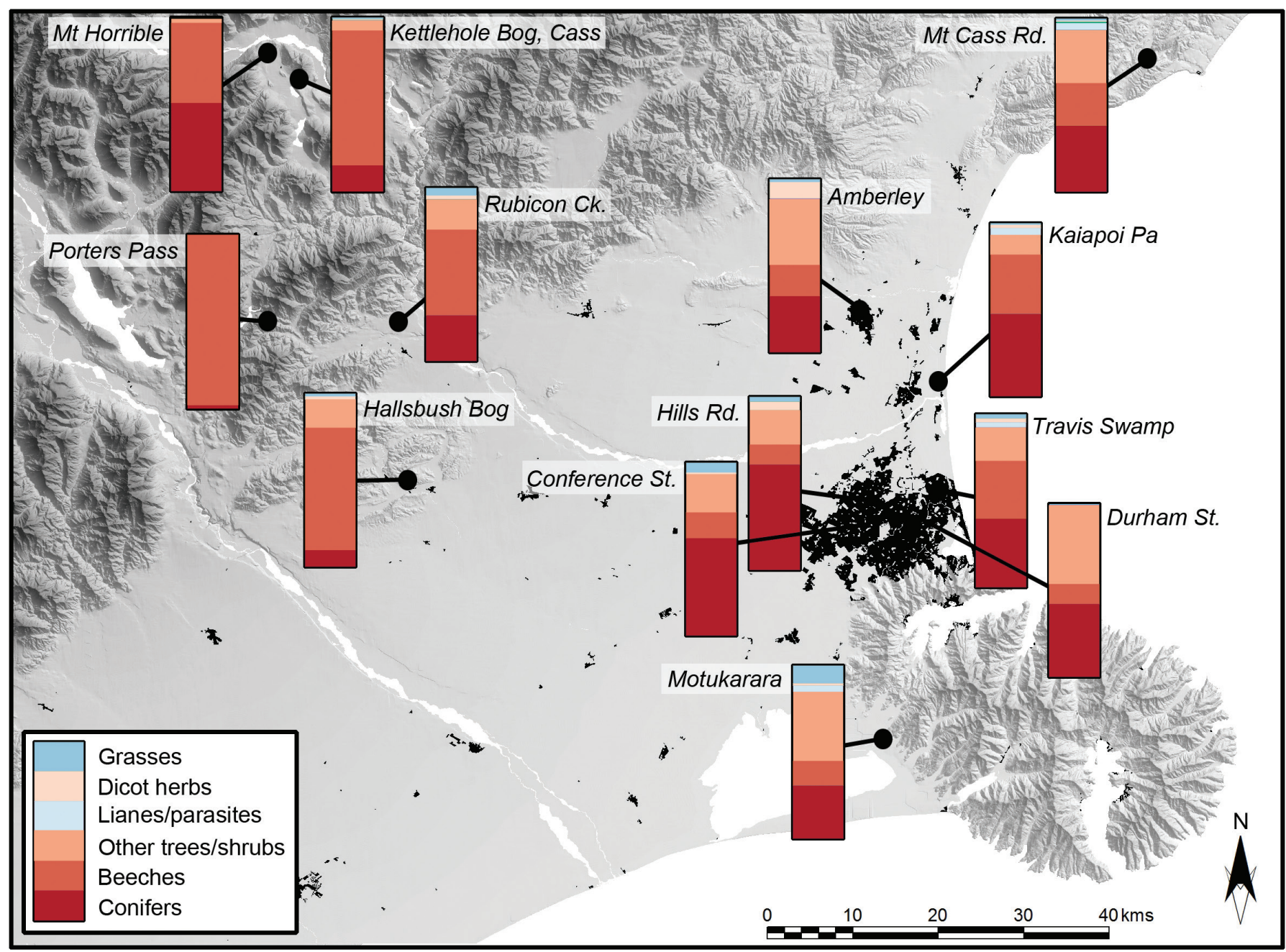

Figure 5. Summary pollen assemblages from the mid-Canterbury region immediately prior to human arrival in New Zealand. Data from Moar 1971 (Amberley, Hills Road, Conference Street), Moar 2008 (Mt. Horrible, Porters Pass, Rubicon Creek, Durham Street), van Dijk 2011 (Motukarara), McGlone et al. 2004 (Kettlehole Bog, Cass) and this study (Hallsbush Bog and Travis Swamp). Ferns are excluded from the pollen sums.

that indicates at the time of human settlement beech forest dominated the western foothills while podocarp/hardwood forest dominated the plains to the east. However, the Canterbury Plains still represent a large geographic void in regards to pollen records (Fig. 5) and the discovery of new pollen-bearing deposits in this area will be critical for better understanding the vegetation history of this part of New Zealand and for guiding restoration schemes on the Canterbury Plains.

\section{Acknowledgements}

We thank Neville Moar and Alison Watkins for assistance with the peat coring, Alison Watkins for preparing the pollen slides, Miles Giller (QEII National Trust) for helpful discussions about the Hallsbush wetland, Nadia Zviagina for help with the Hallsbush pollen analysis and Roger and Shirley Dennis for their hospitality and access to their land. Dr Trevor Partridge assisted with interpretation of the historic record of Travis Swamp. The Travis Swamp record was commissioned by Travis Country Estates Ltd and the Christchurch City Council. Funding for two radiocarbon dates was provided by the QEII National Trust.

\section{References}

Battersby PF, Wilmshurst JM, Curran TJ, McGlone MS, Perry GLW 2017. Exploring fire adaptation in a land with little fire: serotiny in Leptospermum scoparium (Myrtaceae). Journal of Biogeography 44: 1306-1318.

Bronk Ramsey C 1995. Radiocarbon calibration and analysis of stratigraphy: The OxCal program. Radiocarbon 37: 425-430.

Burrows CJ 1995. Amacrofossil flora from sediments in a lagoon marginal to Lake Coleridge, Canterbury, New Zealand. New Zealand Journal of Botany 33: 519-522.

Burrows CJ, Moar NT 1996. A mid Otira Glaciation palaeosol and flora from the Castle Hill Basin, Canterbury, New Zealand. New Zealand Journal ofBotany 34:539-545.

Burrows CJ, Russell JB 1990. Aranuian vegetation history of the Arrowsmith Range, Canterbury I. Pollen diagrams, plant macrofossils, and buried soils from Prospect Hill. New Zealand Journal of Botany 28: 323-345.

Burrows CJ, Randall P, MoarNT, ButterfieldBG 1993. Aranuian vegetation history of the Arrowsmith Range, Canterbury, New Zealand. New Zealand Journal of Botany 31: 147-174. 
Clark RL 1982. Point count estimation of charcoal in pollen preparations and thin sections of sediments. Pollen et Spores 24: 523-535.

ClementAJH, Whitehouse PL, Sloss CR 2016. An examination of spatial variability in the timing and magnitude of Holocene relative sea-level changes in the New Zealand archipelago. Quaternary Science Reviews 131: 73-101.

Cox JE, Mead C 1963. Soil evidence relating to post-glacial climate on the Canterbury Plains. Proceedings of the New Zealand Ecological Society 10: 28-38.

Hogg AG, Hua Q, Blackwell PG, Niu M, Buck CE, Guilderson TP, Heaton TJ, Palmer JG, Reimer PJ, Reimer RW, Turney CSM, Zimmerman SRH 2013. ShCal13 Southern Hemisphere calibration, 0-50,000 years cal BP. Radiocarbon 55: 1889-1903.

Johnson PN 2001. Vegetation recovery after fire on a southern New Zealand peatland. New Zealand Journal of Botany 39: 251-267.

Lintott WH, Burrows CJ 1973. A pollen diagram and macrofossils from Kettlehole Bog Cass, South Island, New Zealand. New Zealand Journal of Botany 11: 269-282.

McGlone MS, Wilmshurst JM 1999. A Holocene record of climate, vegetation change and peat bog development, east Otago, South Island, New Zealand. Journal of Quaternary Science 14: 239-254.

McGlone MS, Turney CSM, Wilmshurst JM2004. Late-glacial and Holocene vegetation and climatic history of the Cass Basin, central South Island, New Zealand. Quaternary Research 62: 267-279.

McKellar MH 1973. Dispersal of Nothofagus pollen in Eastern Otago South Island, New Zealand. New Zealand Journal of Botany 11: 305-310.

McWethy DB, Whitlock C, Wilmshurst JM, McGlone MS, Fromont M, Li X, Dieffenbacher-KrallA, Hobbs WO, Fritz SC, Cook ER 2010. Rapid landscape transformation in South Island, New Zealand, following initial Polynesian settlement. Proceedings of the National Academy of Sciences 107: 21343-21348.

Moar NT 1971. Contributions to the Quaternary history of the New Zealand flora: 6. Aranuian pollen diagrams from Canterbury, Nelson, and North Westland, South Island. New Zealand Journal of Botany 9: 80-145.

Moar NT 1973. Contributions to the Quaternary history of the New Zealand flora: 7. Two Aranuian pollen diagrams from central South Island. New Zealand Journal of Botany 11: 291-303.

Moar NT 2008. Late Quaternary vegetation. In, Winterbourne M, Knox G, Burrows C, Marsden I eds. The Natural History of Canterbury. Christchurch, Canterbury University Press. Pp.169-192.

Moar NT, Gage M 1973. Interglacial deposits in Joyces Stream (S74), Waimakariri Valley, Canterbury. New Zealand Journal of Geology and Geophysics 16: 321-331.

Moar NT, Mildenhall DC 1988. Pollen assemblages from late Quaternary deposits in Canterbury. Appendix 1 in Brown LJ, Wilson DD, Moar NT, Mildenhall DC. Stratigraphy of the late Quaternary deposits of the northern Canterbury Plains, New Zealand. New Zealand Journal of Geology and Geophysics 31: 305-335.

Moar NT, Wilmshurst JM, McGlone MS 2011. Standardizing names applied to pollen and spores in New Zealand Quaternary palynology. New Zealand Journal of Botany 49: 201-229.
Molloy BPJ 1968. Recent history of the vegetation. In: Knox GA ed. The Natural History of Canterbury. Wellington, AH \& AW Reed. Pp. 340-360.

Molloy BPJ 1970. Bankside - a new scientific reserve on the Canterbury Plains. Proceedings of the New Zealand Ecological Society 17: 47-51.

Molloy BPJ, Cox J 1972. Subfossil forest remains and their bearing on forest history in the Rakaia catchment, Canterbury, New Zealand. New Zealand Journal of Botany 10: 267-276.

Molloy BPJ, Ives DW 1972. Biological Reserves of New Zealand 1. Eyrewell Scientific Reserve, Canterbury. New Zealand Journal of Botany 10: 673-700.

Molloy BPJ 2015. The correct name for the New Zealand endemic conifer Hall's totara (Araucariales: Podocarpaceae). Phytotaxa 220: 101-116.

Molloy BPJ, Burrows C, Cox J, Johnston J, Wardle P 1963. Distribution of subfossil forestremains, eastern South Island, New Zealand. New Zealand Journal of Botany 1: 68-77.

Moore PD, Webb JA, Collinson ME 1991. Pollen analysis. Oxford, Blackwell. 216 p.

Myers JV 1973. A note on the dispersal of Nothafagus pollen in Canterbury, New Zealand. New Zealand Journal of Botany 11: 311-316.

Perry GLW, Wilmshurst JM, McGlone MS 2014. Ecology and long-term history of fire in New Zealand. New Zealand Journal of Ecology 38: 157-176.

Raeside JD 1948. Some post-glacial climatic changes in Canterbury and their effects on soil formation. Transactions of the Royal Society of New Zealand 77: 153-171.

Shulmeister J, Soons JM, Berger GW, Harper M, Holt S, Moar N, Carter JA 1999. Environmental and sea-level changes on Banks Peninsula (Canterbury, New Zealand) through three glaciation-interglaciation cycles. Palaeogeography, Palaeoclimatology, Palaeoecology 152: 101-127.

Speight R 1911. The post-glacial climate of Canterbury. Transactions of the New Zealand Institute 43: 408-420.

Timmins SM 1992. Wetland vegetation recovery after fire: Eweburn Bog, TeAnau, New Zealand. New Zealand Journal of Botany 30: 383-399.

Turney CSM, Wilmshurst JM, Jones RT, Wood JR, Palmer J, Hogg A, Fenwick P, Crowley SF, Privat K, Thomas Z 2017. Reconstructing atmospheric circulation over southern New Zealand: Establishment of modern westerly airflow 5500 years ago and implications for Southern Hemisphere Holocene climate change. Quaternary Science Reviews 159: 77-87.

van Dijk JL 2011. Volcanic ash in Holocene valley deposits and its chronostratigraphic implication, Banks Peninsula, Canterbury, New Zealand. Unpublished MSc thesis, Utrecht University, The Netherlands, and Lincoln University, New Zealand.

Wilmshurst JM, McGlone MS, Charman DJ 2002. Holocene vegetation and climate change in southern New Zealand: linkages between forest composition and quantitative surface moisture reconstructions from an ombrogenous bog. Journal of Quaternary Science 17: 653-666.

Woodward CA, Shulmeister J 2005. A Holocene record of human induced and natural environmental change from Lake Forsyth (Te Wairewa), New Zealand. Journal of Paleolimnology 34: 481-501.

Received 18 December 2017; accepted 3 April 2018 Editorial board member: Hannah Buckley 